\title{
Mutation screen and association studies for the fatty acid amide hydrolase (FAAH) gene and early onset and adult obesity
}

\author{
Timo D Müller1,2, Günter Brönner1,3, Melanie Wandolski1, Jophia Carrie1, Trang T Nguyen4, Brandon H Greene4,

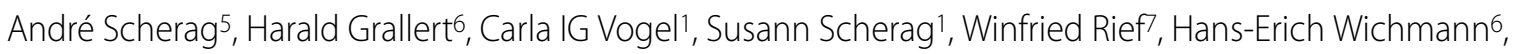 \\ Thomas Illig6, Helmut Schäfer4, Johannes Hebebrand ${ }^{1}$ and Anke Hinney*1
}

\begin{abstract}
Background: The orexigenic effects of cannabinoids are limited by activation of the endocannabinoid degrading enzyme fatty acid amide hydrolase (FAAH). The aim of this study was to analyse whether FAAH alleles are associated with early and late onset obesity.

Methods: We initially assessed association of five single nucleotide polymorphisms (SNPS) in FAAH with early onset extreme obesity in up to 521 German obese children and both parents. SNPs with nominal p-values $\leq 0.1$ were subsequently analysed in 235 independent German obesity families. SNPs associated with childhood obesity (p-values $\leq 0.05$ ) were further analysed in 8,491 adult individuals of a population-based cohort (KORA) for association with adult obesity. One SNP was further analysed in 985 German obese adults and 588 normal and underweight controls. In parallel, we screened the FAAH coding region for novel sequence variants in 92 extremely obese children using singlestranded-conformation-polymorphism-analysis and denaturing HPLC and assessed the implication of the identified new variants for childhood obesity.

Results: The trio analysis revealed some evidence for an association of three SNPs in FAAH (rs324420 rs324419 and rs873978) with childhood obesity (two-sided p-values between 0.06 and 0.10). Although analyses of these variants in 235 independent obesity families did not result in statistically significant effects (two-sided p-values between 0.14 and 0.75), the combined analysis of all 603 obesity families supported the idea of an association of two SNPs in FAAH (rs324420 and rs2295632) with early onset extreme obesity (p-values between 0.02 and 0.03). No association was, however, found between these variants and adult obesity. The mutation screen revealed four novel variants, which were not associated with early onset obesity $(p>0.05)$.
\end{abstract}

Conclusions: As we observed some evidence for an association of the FAAH variants rs2295632 rs324420 with early onset but not adult obesity, we conclude that the FAAH variants analyzed here at least do not seem to play a major role in the etiology of obesity within our samples.

\section{Background}

An emerging body of evidence indicates that the endogenous cannabinoid system is implicated in the regulation of food intake and body weight maintenance. The endocannabinoid system comprises the cannabinoid receptors CNR1 and CNR 2 the endocannabinoids as their endogenous ligands and the enzymes responsible for their biosyn-

\footnotetext{
*Correspondence: anke.hinney@uni-due.de

1 Department of Child and Adolescent Psychiatry and Psychotherapy, University of Duisburg-Essen, Essen, Germany
}

thesis and degradation [1]. The most prominent endocannabinoids are $\mathrm{N}$-arachidonoylethanolamine (anandamide) [2] and 2-arachidonoylglycerol (2-AG) [3]. Both are implicated in the regulation of food intake as exogenous application of anandamide [4,5] and 2-AG [6] stimulate food intake through activation of CNR1. Additionally, hypothalamic levels of both, anandamide and 2-AG are increased in response to fasting and decline upon refeeding [6]. Furthermore, rodents with disturbed leptin signal transduction (ob/ob, $d b / d b$ mice as well as $f a / f a$ rats) show ele- 
vated levels of endocannabinoids in the hypothalamus and leptin treatment of $o b / o b$ mice decreased hypothalamic levels of both anandamide and 2-AG [7].

A characteristic feature of endocannabinoids is that they are synthesized by cells on demand and undergo a rapid degradation through specific hydrolases and lipases $[1,8,9]$. Among these the fatty acid amide hydrolase (FAAH) figure prominently [10]. FAAH is a membrane-bound $60-65 \mathrm{kDa}$ protein that is widely distributed throughout the periphery and the brain with specific central localization in the hypothalamus, hippocampus, brain stem, cerebral cortex and striatum $[10,11]$. Under alkaline conditions, FAAH rapidly inhibits the orexigenic effects of anandamide by degrading it to ethanolamine and arachidonic acid [1]. In accordance to its pivotal role in degradation of anandamide, FAAH mRNA expression is decreased by $59 \%$ in adipose tissue of obese women, as compared to lean controls, whereas circulating levels of anandamide and 2-AG were increased by $35 \%$ and $52 \%$ respectively [12]. Additionally, FAAH activity and expression is decreased in lymphocytes of obese leptin deficient $o b / o b$ mice [13] and leptin mediated STAT3 activation activates a CRE-like binding site on the FAAH promoter [14]. Furthermore, association with obesity had recently been reported for the A/A genotype of the FAAH SNP rs324420 [15]. The SNP leads to the non-synonymous exchange from proline to threonine at position 129 of the FAAH protein (Pro129Thr). Functional in-vitro studies further revealed that the 129Thr variant decreased the expression and activity of FAAH in humans, thus seemingly corroborating the implication of the A-allele at rs324420 in human obesity [16]. However, other studies could not substantiate the association of rs324420 with obesity [17-19].

As FAAH counteracts the orexigenic effects of endocannabinoids through their rapid degradation, genetic variation in $F A A H$ that leads to decreased enzyme activity and thus increased levels of endocannabinoids might be implicated in the etiology of obesity. The aim of this study was therefore to test for association of selected gene variants in $F A A H$ with obesity.

\section{Methods \\ Study subjects}

The ascertainment strategy was previously described in detail [20]. The (extremely) obese children and adolescents had age and gender specific BMI percentiles above $90^{\text {th }}$ (70\% above $\left.99^{\text {th }}\right)$. Written informed consent was given by all participants and in the case of minors, by their parents. The study was approved by the Ethics Committees of the Universities of Marburg and Duisburg-Essen and carried out according to the Declaration of Helsinki.

The obesity trios comprised 521 (233 male) German (extremely) obese children and adolescents (mean BMI of $31.86 \pm 5.99 \mathrm{~kg} / \mathrm{m}^{2}$, mean BMI percentile: 98.98 mean age $13.42 \pm 3.09$ years) and both biological parents. The parents had a mean BMI of $30.02 \pm 6.38 \mathrm{~kg} / \mathrm{m}^{2}$ and a mean age of $42.32 \pm 6.07$ years.

The 235 independent obesity families included 501 (229 male) German (extremely) obese children and adolescents (235 obese index patients and at least one obese sibling) and both biological parents. The index patients had a mean BMI of $32.28 \pm 5.91 \mathrm{~kg} / \mathrm{m}^{2}$ (mean BMI percentile $99.25 \pm 1.48)$ and a mean age of $13.40 \pm 2.63$ years, the siblings had a mean BMI of $28.57 \pm 5.29 \mathrm{~kg} / \mathrm{m}^{2}$ (mean BMI percentile $97.37 \pm 2.85)$ and a mean age of $15.15 \pm 5.09$ years. The parents had a mean BMI of $31.07 \pm 6.03 \mathrm{~kg} / \mathrm{m}^{2}$ and a mean age of $43.06 \pm 5.81$ years.

The epidemiological cohort comprised 8,491 (4,250 male) adult individuals of a German population-based study group [KORA S3-S4]. The KORA sample is a representative study group of the population in the city and region of Augsburg (Bavaria, Germany) [21]. The here reported 8,491 individuals had a mean age of $49.3 \pm 27.12$ years and a mean BMI of $27.12 \pm 4.59 \mathrm{~kg} / \mathrm{m}^{2}$.

The case-control sample comprised 985 (360 male) German obese adults (mean BMI: $36.04 \pm 5.39 \mathrm{~kg} / \mathrm{m}^{2}$; mean age: $46.31 \pm 14.74$ years) and 588 healthy normal and underweight controls (mean BMI: $19.34 \pm 1.94 \mathrm{~kg} / \mathrm{m}^{2}$; mean age: $25.28 \pm 4.42$ years). All individuals were independent from the KORA cohort und all cases had a BMI at or above $30 \mathrm{~kg} / \mathrm{m}^{2}$. The use of lean adults who were never overweight or obese during childhood (assessed by interview, [22]) as control group reduces the chances of misclassification compared to the use of lean children as controls who might become overweight in adulthood [22]

The FAAH coding region was screened in 92 German extremely obese children and adolescents of the trio samples who contributed to the initially observed overtransmission of the rs2295632 G-allele (Table 1). The screened individuals had a mean BMI of $33.61 \pm 7.21 \mathrm{~kg} / \mathrm{m}^{2}$ (mean BMI percentile $99.2 \pm 1.88$ ) and a mean age of $14.13 \pm 3.08$ years. Association of the identified novel variants with early onset extreme obesity was assessed in the 521 German obesity trios.

\section{Molecular genetic methods Genotyping}

We initially assessed association of five SNPs in FAAH (rs324420, rs324419, rs873978, rs2295632 and rs932816) with early onset extreme obesity. SNP rs324420, rs324419, rs873978 and rs2295632 were genotyped in 368 German obesity trios using matrix-assisted laser desorption/ionization time-of-flight mass spectrometry (MALDI-TOF MS, Sequenom, San Diego, CA). The FAAH promoter SNP rs932816 was genotyped in 521 German obesity trios using restriction-fragment length polymorphism analyses (PCRRFLP). SNPs with nominal TDT p-values $\leq 0.1$ were subsequently analysed in additional 235 independent obesity families. The 8,491 adult individuals of the population- 
Table 1: Genotypes and TDT results of the analysed SNPs in FAAH in the obesity trios

\begin{tabular}{|c|c|c|c|c|c|c|c|}
\hline SNP1 & Position ${ }^{2}$ & $\begin{array}{l}\text { Location } \\
\text { exchange }\end{array}$ & $\mathbf{N}^{3}$ & $\begin{array}{l}\text { Genotypes (fre- } \\
\text { quency } \%)^{4}\end{array}$ & $\begin{array}{l}\text { Allele } \\
\text { frequ. } \%^{5}\end{array}$ & Transm. rate $^{6}$ & $\begin{array}{c}\text { TDT } \\
\text { p-value }\end{array}$ \\
\hline & & & & GG $243(0.478)$ & G: 0.68 & & \\
\hline & & putative & & GA 209 (0.412) & & & \\
\hline \multirow[t]{3}{*}{ rs932816 } & g. $-272 \mathrm{G} / \mathrm{A}$ & promoter & 508 & AA $56(0.110)$ & A: 0.32 & $0.53(\mathrm{~A})$ & 0.14 \\
\hline & & Exon 3, & & CC $248(0.690)$ & C: 0.83 & & \\
\hline & & & & CA $101(0.282)$ & & & \\
\hline \multirow[t]{3}{*}{ rs324420 } & c. $385 \mathrm{C} / \mathrm{A}$ & Pro129Thr & 359 & AA $10(0.028)$ & A: 0.17 & $0.44(\mathrm{~A})$ & 0.06 \\
\hline & & Exon 7 & & GG $258(0.730)$ & G: 0.85 & & \\
\hline & & & & GA 87 (0.247) & & & \\
\hline \multirow[t]{3}{*}{ rs324419 } & c.895A/G & Cys299Cys & 353 & AA $8(0.023)$ & A: 0.15 & $0.44(\mathrm{~A})$ & 0.08 \\
\hline & & & & GG 351 (0.978) & G: 0.99 & & \\
\hline & & & & GA 8 (0.022) & & & \\
\hline \multirow[t]{3}{*}{ rs873978 } & IVS7-228G/A & Intron 7 & 359 & AA $0(0.000)$ & $A: 0.01$ & $0.88(\mathrm{~A})$ & 0.10 \\
\hline & & & & GG $214(0.610)$ & G: 0.77 & & \\
\hline & & & & GT $113(0.322)$ & & & \\
\hline rs2295632 & ${ }^{*} 45 \mathrm{G} / \mathrm{T}$ & 3 ' region & 351 & ТT 24 (0.068) & $\mathrm{T}: 0.23$ & $0.44(\mathrm{~T})$ & 0.05 \\
\hline
\end{tabular}

based KORA cohort were analyzed using MALDI-TOF mass spectrometry. Additionally, we genotyped the $F A A H$ SNP rs324420 in 985 independent German obese adults and 588 normal or underweight controls using PCR-RFLP.

\section{Mutation screening}

Single stranded conformation polymorphism analysis (SSCP) and denaturing high pressure liquid chromatography (dHPLC) were performed 92 extremely obese children and adolescents which mainly contributed to the observed overtransmission of the rs2295632 G-allele (Table 1). The coding region of FAAH plus 79 nucleotides (nt) of the 5'untranslated region (UTR) and 154nt of 3'-UTR was amplified from genomic DNA using PCRs to yield 17 fragments. The corresponding primer sequences, PCR conditions and restriction enzymes can be obtained from the authors. SSCP and dHPLC were performed as described previously [23]. All amplicons with SSCP or dHPLC patterns deviant from wild type patterns were re-sequenced as described [22]. The implication of the identified novel variants in $F A A H$ for childhood obesity was subsequently assessed in 521 German obesity trios using PCR-RFLP or Taqman ${ }^{\circledR}$ genotyping followed by TDT analyses [24].

\section{TaqMan assay}

the identified rare FAAH SNP rs41305628 was genotyped using TaqMan ${ }^{\circledR}$ allelic discrimination assay (Applied Biosystems, Germany), call rates $>95 \%$, with $100 \%$ concordance of duplicates, using a Custom Assay. For validity of the genotypes, alleles were rated independently by at least two experienced individuals. Discrepancies were resolved unambiguously either by reaching consensus or by retyping.

\section{Statistics}

Using Haploview 4.0 we estimated that the analyzed five SNPs cover the common genetic variability of FAAH with a mean max $r^{2}$ of 0.48 (assuming a minor allele frequency cut-off of $5 \%$ to define common variation using the HapMap data for the European population), Tests for Hardy- 
Weinberg equilibrium were carried out using an exact test [25]. To identify the most promising SNPs for replication studies, we first performed association analyses for five SNPs in up to 521 obesity trios using the transmission-disequilibrium tests (TDT) [24]. SNPs with nominal $p$ values $\leq 0.1$ were subsequently analysed in additional 235 independent obesity families applying the pedigree disequilibrium test (PDT) [26]. We further considered both independent datasets in a combined analysis comprising the initial trios and the 235 obesity families using the PDT. For each SNP we also assessed multiplicative genotype relative risks (GRR) with a $95 \%$ confidence interval $(95 \%$-CI) based on the ideas of Cordell and Clayton [27] using the stata package 'gamenu' http://www-gene.cimr.cam.ac.uk/ clayton/software/stata/ which leads to some minor differences regarding p-values when compared to the PDT results due to differences in estimation.

SNPs with nominal PDT $p$-values $\leq 0.05$ in the combined analyses were consecutively analysed in the populationbased KORA cohort regarding adult obesity. We stratified the KORA probands into obese cases (BMI $\geq 30 \mathrm{~kg} / \mathrm{m}^{2}, \mathrm{~N}=$ 1,858 ) and normal or underweight controls (BMI $<25 \mathrm{~kg} /$ $\mathrm{m}^{2}, \mathrm{~N}=2,818$ ) and applied logistic regression using gender and age as covariates and coding genotypes under a logadditive genetic model. Assuming that the GRRs we estimated from the combined family sample are also observable in adults, we would have been able to confirm the association of these three variants with an estimated power between $80 \%$ and $97 \%$. Sensitivity analyses assessing BMI quantitatively by linear regression in all KORA probands, generally supported our conclusions drawn below in the results section. The strongest BMI effect per allele was 0.07 $\mathrm{kg} / \mathrm{m}^{2}(\mathrm{p}=0.41)$ for SNP rs2295632. Note that a population-based sample of 8,491 individuals would have a statistical power $\geq 80 \%$ to detected much stronger BMI effects (about $0.2 \mathrm{~kg} / \mathrm{m}^{2}$ ) only (given all other assumptions being similar to those in the nuclear families).

Association analysis for FAAH SNP rs324420 was also performed in an additional independent 985 obese cases and 588 lean and normal weight controls using the Cochran-Armitage exact trend test. This case-control sample has a power of about $60 \%$ to confirm the GRR effect observed in the initial combined family sample for rs324420.

All reported p-values are two-sided, nominal and not corrected for multiple testing. Power calculations were performed using the program QUANTO http://hydra.usc.edu/ GxE applying a significance level of 5\%, the observed multiplicative GRRs from the family sample (1.15-1.23) and the corresponding frequencies of the risk alleles $(70 \%$ $81 \%)$ under a (log-) additive genetic model.

\section{Results}

No evidence for deviations from Hardy-Weinberg equilibrium was observed in all independent study groups (all exact $\mathrm{p}>0.05$ ). Analyses of five SNPs in FAAH in up to 521 German obesity trios revealed some evidence for an association of the G-allele at rs 2295632 with early onset extreme obesity (transmission rate of the G-allele 0.56; nominal $\mathrm{p}=0.045$ Table 1). Moreover, we observed some evidence for transmission disequilibrium for three other FAAH SNPs (rs324420 rs324419 and rs873978) in the obesity trios (nominal two-sided p-values between 0.06 and 0.10 Table 1). Analyses of these four variants in additional 235 independent obesity families could not substantiate this observation (nominal two-sided p-values between 0.14 and 0.75 Table 2). However, as the small sample size of this group might have contributed to the observed lack of association, we subsequently considered both independent datasets jointly. In the combined analyses of the 603 obesity families we observed some evidence for an association of two SNPs in FAAH (rs324420 and rs2295632 $\mathrm{r}^{2}: 0.69$ ) with childhood obesity (nominal two-sided p-values of 0.02 and 0.03 Table 2). Similarly, haplotype analysis for rs 324420 and rs2295632 alleles supported this observation (omnibus two-sided nominal $\mathrm{p}=0.0387$ Table 3 ). However, in the population-based study we observed no evidence for an association of the two variants with adult obesity (all $\mathrm{p} \geq$ 0.05; Table 4) or BMI (see Methods). Also analyses of rs 324420 in 985 German obese adults and 588 normal and underweight controls revealed no association with adult obesity (nominal two-sided $\mathrm{p}=0.85$ ).

In the mutation screen, we detected nine sequence variants, four of them are novel (Table 5). However, analyses of the rare (minor allele frequency $<0.1$ ) variants (IVS1+22G/ A, rs41305628 and IVS12-5C/T) in 521 German obesity trios revealed no evidence for association of these variants with early onset extreme obesity (all two-sided $p \geq 0.05$ ).

\section{Discussion}

Analyses of five SNPs in FAAH in up to 521 German obesity trios and 235 independent obesity families revealed nominal evidence for association of two FAAH SNPs (rs324420 and rs2295632) with early onset extreme obesity. The FAAH SNP rs324420 A-allele has recently been reported to be associated with drug and alcohol abuse [28] and obesity [15]. Functional in-vitro studies further revealed that expression and activity of FAAH is reduced in isolated peripheral circulating T-lymphocytes of homozygotes for the rs 324420 A-allele, thus seemingly underlining the observed association of rs324420 with obesity [16]. However, several other studies could not confirm the association of the rs324420 A-allele with obesity [17-19]. In this study we also report lack of association of the rs 324420 A-allele with obesity. Instead, we observed some evidence for an association of the C-allele at rs324420 with child- 
Table 2: Genotypes and PDT results of the independent analysis of 235 obesity families and combined analyses of a total of 603 obesity families

\begin{tabular}{|c|c|c|c|c|c|c|}
\hline SNP1 & $\mathbf{N}^{3}$ & $\begin{array}{l}\text { Genotypes (fre- } \\
\text { quency \%) }\end{array}$ & Allele frequ. $\%^{5}$ & Transm. rate ${ }^{6}$ & $\begin{array}{l}\text { PDT p-value } \\
\text { for } 235 \\
\text { independent } \\
\text { families }\end{array}$ & $\begin{array}{l}\text { PDT p-value and } \\
\text { GRR with } 95 \%-C l \\
\text { on } 603 \text { families } 7\end{array}$ \\
\hline \multirow[t]{3}{*}{ rs324420 } & 494 & CC $320(0.648)$ & $C: 0.802$ & $0.47(A)$ & 0.14 & $\begin{array}{c}0.02 \\
(1.23,1.03-1.48)\end{array}$ \\
\hline & & CA 152 (0.308) & & & & \\
\hline & & AA $22(0.044)$ & A: 0.198 & & & \\
\hline \multirow[t]{3}{*}{ rs324419 } & 491 & GG 350 (0.713) & G: 0.838 & $0.51(A)$ & 0.75 & $\begin{array}{c}0.18 \\
(0.94,0.77-1.15)\end{array}$ \\
\hline & & GA $123(0.251)$ & & & & \\
\hline & & AA 18 (0.036) & A: 0.162 & & & \\
\hline \multirow[t]{3}{*}{ rs873978 } & 494 & GG 485 (0.982) & G: 0.991 & $0.49(A)$ & 0.56 & $\begin{array}{c}0.08 \\
(2.50,0.97-6.44)\end{array}$ \\
\hline & & GA 9 (0.018) & & & & \\
\hline & & AA $0(0.000)$ & A: 0.001 & & & \\
\hline \multirow[t]{3}{*}{ rs2295632 } & 496 & GG 266 (0.536) & G: 0.732 & $0.483(\mathrm{~T})$ & 0.32 & $\begin{array}{c}0.03 \\
(1.15,0.98-1.35)\end{array}$ \\
\hline & & GT 194 (0.391) & & & & \\
\hline & & ТТ 36 (0.073) & $\mathrm{T}: 0.268$ & & & \\
\hline \multicolumn{7}{|c|}{$\begin{array}{l}{ }^{1} \text { all SNPs were tested for Hardy-Weinberg equilibrium }(p>0.05) ;{ }^{2} \text { numbers are given according to Dunnen and Antonarakis } 2001 \text { Hum Genet } \\
109: 121-124[33] ;{ }^{3} \text { number of obese children or adolescents of the } 235 \text { obesity families; }{ }^{4} \text { genotype frequencies in the index patients of the } \\
235 \text { obesity families; }{ }^{5} \text { allele frequencies in the obese children or adolescents of the } 235 \text { obesity families. These are very similar to the allele } \\
\text { frequencies reported for the European population in the dbSNP database http://www.ncbi.nlm.nih.gov/SNP/; }{ }^{6} \text { transmission rate of minor } \\
\text { allele in } 235 \text { obesity families; }{ }^{7} \mathrm{p} \text {-value of the combined analyses of the } 603 \text { obesity families. }\end{array}$} \\
\hline
\end{tabular}

hood obesity. In light of these contradictory findings pertaining to the association of rs 324420 alleles with obesity, it has to considered that associations of genetic variants with complex phenotypes may vary with age [29] and ascertainment scheme [30]. Accordingly, in the population-based study, we observed no association of this variant with adult obesity. Also analyses of rs 324420 in 985 German obese adults and 588 normal weight controls did not provide evidence for an association. Due to discrepant results pertaining to the implication of SNP rs324420 with obesity, analyses of this variant in larger study groups are necessary to clarify whether this variant is implicated in the etiology of obesity. One of the limitations of our study is that the here analyzed variants cover the common genetic variability of $F A A H$ with a mean $\max \mathrm{r}^{2}$ of 0.48 . Thus, it is possible that other common variants which are not in LD with the analyzed variants, might be of greater importance in the eti- ology of childhood and/or adult obesity. However, although rather small our mutation analysis in 93 obese children and adolescents did not hint to a major impact of additional mutations in FAAH in weight regulation. Moreover, FAAH variants were not reported among the top-hits of recent meta-analyses of genome-wide association studies for BMI or obesity $[31,32]$; potentially also indicating their minor importance for the etiology of obesity.

\section{Conclusions}

In summary we observed some evidence for an association of two SNPs in FAAH (rs324420 and rs2295632) with early onset but not adult obesity. This finding is in line with previous results showing lack of association of rs324420 with adult obesity in a large population-based study [17]. As our data were not corrected for multiple testing, we thus conclude that the $F A A H$ variants analysed here may play a 
Table 3: Haplotype analysis of the FAAH SNPs rs324420 and rs2295632 in the 603 obesity families

\begin{tabular}{cccccc}
\hline rs324420 & rs2295632 & Frequency & Transmitted & Nontransmitted & Transmissionrate ${ }^{1,2}$ \\
\hline A & T & 0.197 & 232 & 288 & 0.806 \\
C & T & 0.064 & 99 & 94 & 1.053 \\
A & G & 0.000 & 0 & 0 & - \\
C & G & 0.739 & 340 & 289 & 1.176 \\
\hline
\end{tabular}

${ }^{1}$ Number of haplotypes were estimated by the EM-algorithm [34]; ${ }^{2}$ omnibus $p$-value for association is $p=0.0387$

major role in the genetic etiology of obesity within our samples. To finally answer this question, further studies in larger sample preferentially child and adolescents with an extreme phenotype should be analysed.

\section{Competing interests}

The authors declare that they have no competing interests.

\section{Authors' contributions}

TDM helped to carry out the molecular genetic studies, participated in design and interpretation of data and drafted the manuscript. MW and JC carried out the mutation screen under supervision of GB. GB and SS also participated in the study design and interpretation of data. TTN and BG performed the statistical analysis and helped to draft the manuscript under supervision of AS and HS. HG carried out the molecular genetic studies using MALDI-TOF mass spec- trometry under supervision of $\mathrm{TI}$ and $\mathrm{H}$-EW. TI, H-EW and WR made substantial contributions to the acquisition of data and contributed to the conception, design and interpretation of data. $\mathrm{JH}$ and $\mathrm{AH}$ conceived the design and directed study coordination; helped to draft the manuscript and revised it critically. All authors read and approved the final manuscript.

\section{Acknowledgements}

This work was supported by grants from the Federal Ministry of Education and Research (NGFN2: 01GS048201GS0483; NGFNPlus: 01GS0820), the European Union (FP6 LSHMCT-2003-503041) and the Deutsche Forschungsgemeinschaft (DFG; HE 1446/4-1). The skillful technical assistance of Jitka Andrae and Siglinde Düerkop is highly appreciated.

Table 4: Genotype frequencies and results of association analyses in the population-based KORA sample

\begin{tabular}{|c|c|c|c|c|c|c|}
\hline SNP & BMI & $\begin{array}{c}\text { Genotype } \\
\text { frequency N (\%) }\end{array}$ & $\begin{array}{c}\text { Allele } \\
\text { frequency } \\
(\%)\end{array}$ & OR $^{1}$ & $95 \% \mathrm{Cl}$ & p-value ${ }^{2}$ \\
\hline \multirow[t]{5}{*}{ rs2295632 } & $<25$ & CC $1575(0.560)$ & $C: 0.75$ & 1.01 & $0.91-1.12$ & 0.91 \\
\hline & & CA 1068 (0.379) & & & & \\
\hline & $\geq 30$ & CC 1051 (0.567) & $C: 0.75$ & & & \\
\hline & & CA 685 (0.369) & & & & \\
\hline & & AA $119(0.064)$ & A: 0.25 & & & \\
\hline \multirow{5}{*}{ rs324420 } & & CA $855(0.303)$ & & & & \\
\hline & & AA $87(0.031)$ & A: 0.18 & & & \\
\hline & $\geq 30$ & CC $1240(0.668)$ & C: 0.81 & & & \\
\hline & & CA $547(0.294)$ & & & & \\
\hline & & AA 71 (0.038) & A: 0.19 & & & \\
\hline
\end{tabular}

${ }^{1}$ Odds ratios (OR) of the respective minor alleles were adjusted for sex and age; ${ }^{2}$ Association tests were performed applying generalized linear model with the log-transformed binomial link function; $p$-values are two-sided and not corrected for multiple testing. 
Table 5: FAAH: results of a mutation screen in 92 German extremely obese children and adolescents

\begin{tabular}{|c|c|c|c|c|c|c|}
\hline Gene & SNP & Position 1 & $\begin{array}{l}\text { Location } \\
\text { Exchange }\end{array}$ & Genotypes n (\%)2, & $\begin{array}{l}\text { Allele } \\
(\%)^{3}, 4\end{array}$ & frequency \\
\hline \multirow[t]{3}{*}{ FAAH } & & $\mathrm{IVS} 1+22 \mathrm{G} / \mathrm{A}$ & Intron 1 & GG $31(0.337)$ & & G: 0.60 \\
\hline & & & & GA $49(0.533)$ & & \\
\hline & & & & AA $12(0.130)$ & & A: 0.40 \\
\hline \multirow[t]{3}{*}{ FAAH } & rs324420 & c. $385 \mathrm{C} / \mathrm{A}$ & Exon 3 & CC $82(0.901)$ & & C: 0.95 \\
\hline & & & & CA 09 (0.099) & & \\
\hline & & & Pro129Thr & AA $00(0.000)$ & & A: 0.05 \\
\hline \multirow[t]{3}{*}{ FAAH } & & c. $611 \mathrm{C} / \mathrm{T}$ & Exon 5 & CC 90 (0.989) & & C: 0.99 \\
\hline & & & & СТ 01 (0.011) & & \\
\hline & & & Thr204lle & ТT $00(0.000)$ & & $\mathrm{T}: 0.01$ \\
\hline \multirow[t]{3}{*}{ FAAH } & & c.690C/G & Exon 5 & CC 90 (0.989) & & C: 0.99 \\
\hline & & & & CG 01 (0.011) & & \\
\hline & & & Ser230Ser & GG $00(0.000)$ & & G: 0.01 \\
\hline \multirow[t]{3}{*}{ FAAH } & rs41305628 & c. $822 \mathrm{G} / \mathrm{A}$ & Exon 6 & GG $88(0.957)$ & & G: 0.98 \\
\hline & & & & GA 04 (0.043) & & \\
\hline & & & Glu274Glu & AA $00(0.000)$ & & $A: 0.02$ \\
\hline \multirow[t]{3}{*}{ FAAH } & rs41309147 & IVS6-41G/A & Intron 6 & GG 77 (0.837) & & G: 0.92 \\
\hline & & & & GA $15(0.163)$ & & \\
\hline & & & & AA $00(0.000)$ & & A: 0.08 \\
\hline \multirow[t]{3}{*}{ FAAH } & rs324419 & C. $895 \mathrm{C} / \mathrm{T}$ & Exon 7 & CC $70(0.761)$ & & C: 0.88 \\
\hline & & & & CT 22 (0.239) & & \\
\hline & & & Cys299Cys & Tा $00(0.000)$ & & $\mathrm{T}: 0.12$ \\
\hline \multirow[t]{3}{*}{ FAAH } & & IVS12-5C/T & Intron 12 & CC 79 (0.859) & & C: 0.93 \\
\hline & & & & СТ $13(0.141)$ & & \\
\hline & & & & ТТ $00(00.00)$ & & $\mathrm{T}: 0.07$ \\
\hline \multirow[t]{3}{*}{ FAAH } & rs2295632 & IVS15+45G/T & 3'UTR & GG 18 (0.196) & & $\mathrm{T}: 0.60$ \\
\hline & & & & GT 74 (0.804) & & \\
\hline & & & & ТТ $00(00.00)$ & & G: 0.40 \\
\hline
\end{tabular}

${ }^{1}$ numbers are given according to Dunnen and Antonarakis 2001 Hum Genet 109:121-124 [33]; ${ }^{2}$ genotype frequencies in the 92 individuals used for the mutation screen; ${ }^{3}$ allele frequencies in the 92 individuals used for the mutation screen. ${ }^{4} \mathrm{As}$ the mutation screen was performed in those individuals who contributed to the initially observed overtransmission of the FAAH SNP rs $2295632 \mathrm{G}$-allele, this SNP is therefore not in Hardy-Weinberg-Equilibrium in these samples. 


\section{Author Details}

'Department of Child and Adolescent Psychiatry and Psychotherapy, University of Duisburg-Essen, Essen, Germany, ${ }^{2}$ Department of Psychiatry, University of Cincinnati, Genome Research Institute, Cincinnati, OH, USA, ${ }^{3}$ Biocenter of the University of Wuerzburg, Wuerzburg, Germany, ${ }^{4}$ Institute of Medical Biometry and Epidemiology, Philipps-University Marburg, Marburg, Germany, 5 Institute for Medical Informatics, Biometry and Epidemiology, University of Duisburg-Essen, Essen, Germany, ${ }^{6} \mathrm{Helmholtz}$ Zentrum Muenchen, Deutsches Forschungszentrum fuer Gesundheit und Umwelt, Neuherberg, Germany and 7 Department of Clinical Psychology and Psychotherapy, Philipps-University Marburg, Marburg, Germany

Received: 6 April 2009 Accepted: 1 January 2010

Published: 1 January 2010

\section{References}

1. Di Marzo V, Bifulco M, De Petrocellis $L$ : The endocannabinoid system and its therapeutic exploitation. Nat Rev Drug Discov 2004, 3:771-784.

2. Devane WA, Hanus L, Breuer A, Pertwee RG, Stevenson LA, Griffin G, Gibson D, Mandelbaum A, Etinger A, Mechoulam R: Isolation and structure of a brain constituent that binds to the cannabinoid receptor. Science 1992, 258:1946-1949.

3. Sugiura T, Kondo S, Sukagawa A, Nakane S, Shinoda A, Itoh K, Yamashita A, Waku K: 2-Arachidonoylglycerol: a possible endogenous cannabinoid receptor ligand in brain. Biochem Biophys Res Commun 1995, 215:89-97.

4. Williams CM, Kirkham TC: Anandamide induces overeating: mediation by central cannabinoid (CB1) receptors. Psychopharmacology (Berl) 1999, 143:315-317.

5. Williams CM, Kirkham TC: Observational analysis of feeding induced by Delta9-THC and anandamide. Physiol Behav 2002, 76:241-250.

6. Kirkham TC, Williams CM, Fezza F, Di Marzo V: Endocannabinoid levels in rat limbic forebrain and hypothalamus in relation to fasting, feeding and satiation: stimulation of eating by 2-arachidonoyl glycerol. $\mathrm{Br} J$ Pharmacol 2002, 136:550-557.

7. Di Marzo V, Goparaju SK, Wang L, Liu J, Bátkai S, Járai Z, Fezza F, Miura GI, Palmiter RD, Sugiura T, Kunos G: Leptin-regulated endocannabinoids are involved in maintaining food intake. Nature 2001, 410:822-825.

8. Di Marzo V, De Petrocellis L, Bisogno T, Melck D: Metabolism of anandamide and 2-arachidonoylglycerol: an historical overview and some recent developments. Lipids 1999, 34(Suppl):S319-325.

9. Dinh TP, Carpenter D, Leslie FM, Freund TF, Katona I, Sensi SL, Kathuria S, Piomelli D: Brain monoglyceride lipase participating in endocannabinoid inactivation. Proc Natl Acad Sci USA 2002, 99:10819-10824.

10. Puffenbarger RA: Molecular biology of the enzymes that degrade endocannabinoids. Curr Drug Targets CNS Neurol Disord 2005, 4:625-631.

11. Hillard CJ, Wilkison DM, Edgemond WS, Campbell WB: Characterization of the kinetics and distribution of $\mathrm{N}$-arachidonylethanolamine (anandamide) hydrolysis by rat brain. Biochim Biophys Acta 1995, 257:249-256.

12. Engeli S, Böhnke J, Feldpausch M, Gorzelniak K, Janke J, Bátkai S, Pacher P, Harvey-White J, Luft FC, Sharma AM, Jordan J: Activation of the peripheral endocannabinoid system in human obesity. Diabetes 2005 54:2838-2843

13. Maccarrone M, Di Rienzo M, Finazzi-Agrò A, Rossi A: Leptin activates the anandamide hydrolase promoter in human T lymphocytes through STAT3. J Biol Chem 2003, 278:13318-13324.

14. Lambert DM, Muccioli GG: Endocannabinoids and related Nacylethanolamines in the control of appetite and energy metabolism: emergence of new molecular players. Curr Opin Clin Nutr Metab Care 2007, 10:735-744

15. Sipe JC, Waalen J, Gerber A, Beutler E: Overweight and obesity associated with a missense polymorphism in fatty acid amide hydrolase (FAAH). Int J Obes (Lond) 2005, 29:755-759.

16. Chiang KP, Gerber AL, Sipe JC, Cravatt BF: Reduced cellular expression and activity of the P129T mutant of human fatty acid amide hydrolase: evidence for a link between defects in the endocannabinoid system and problem drug use. Hum Mol Genet 2004, 13:2113-2119.

17. Jensen DP, Andreasen CH, Andersen MK, Hansen L, Eiberg H, BorchJohnsen K, Jørgensen T, Hansen T, Pedersen O: The functional Pro129Thr variant of the FAAH gene is not associated with various fat accumulation phenotypes in a population-based cohort of 5,801 whites. J Mol Med 2007, 85:445-449.

18. Papazoglou D, Panagopoulos I, Papanas N, Gioka T, Papadopoulos T, Papathanasiou P, Kaitozis O, Papatheodorou K, Maltezos E: The Fatty Acid Amide Hydrolase (FAAH) Pro129Thr Polymorphism is not Associated with Severe Obesity in Greek Subjects. Horm Metab Res 2008, 40:907-910.

19. Lieb W, Manning AK, Florez JC, Dupuis J, Cupples LA, McAteer JB, Vasan RS, Hoffmann U, O'Donnell CJ, Meigs JB, Fox CS: Variants in the CNR1 and the FAAH Genes and Adiposity Traits in the Community. Obesity (Silver Spring) 2009, 17:755-760

20. Hinney A, Hinney A, Bettecken T, Tarnow P, Brumm H, Reichwald K, Lichtner P, Scherag A, Nguyen TT, Schlumberger P, Rief W, Vollmert C, Illig T, Wichmann HE, Schäfer H, Platzer M, Biebermann H, Meitinger T, Hebebrand J: Prevalence, spectrum, and functional characterization of melanocortin-4 receptor gene mutations in a representative population-based sample and obese adults from Germany. Clin Endocrinol Metab 2006, 91:1761-1769.

21. Holle R, Happich M, Lowel H, Wichmann HE, MONICA/KORA Study Group: KORA: a research platform for population based health research. Gesundheitswesen 2005, 67(Suppl 1):S19-S25.

22. Hinney A, Nguyen TT, Scherag A, Friedel S, Brönner G, Müller TD, Grallert H, Illig T, Wichmann HE, Rief W, Schäfer H, Hebebrand J: Genome wide association (GWA) study for early onset extreme obesity supports the role of fat mass and obesity associated gene (FTO) variants. PLOS ONE 2007, 2:e1361.

23. Hinney A, Hohmann S, Geller F, Vogel C, Hess C, Wermter AK, Brokamp B, Goldschmidt H, Siegfried W, Remschmidt H, Schäfer H, Gudermann T, Hebebrand J: Melanocortin-4 receptor gene: case-control study and transmission disequilibrium test confirm that functionally relevant mutations are compatible with a major gene effect for extreme obesity. J Clin Endocrinol Metab 2003, 88:4258-4267.

24. Spielman RS, McGinnis RE, Ewens WJ: Transmission test for linkage disequilibrium: the insulin gene region and insulin-dependent diabetes mellitus (IDDM). Am J Hum Genet 1993, 52:506-516.

25. Wigginton JE, Cutler DJ, Abecasis GR: A note on exact tests of HardyWeinberg equilibrium. Am J Hum Genet 2005, 76:887-893.

26. Martin ER, Monks SA, Warren LL, Kaplan NL: A test for linkage and association in general pedigrees: the pedigree disequilibrium test. $\mathrm{Am}$ $J$ Hum Genet 2000, 67:146-154

27. Cordell HJ, Clayton DG: A unified stepwise regression procedure for evaluating the relative effects of polymorphisms within a gene using case/control or family data: application to HLA in type 1 diabetes. Am J Hum Genet 2002, 70:124-141.

28. Sipe JC, Chiang K, Gerber AL, Beutler E, Cravatt BF: A missense mutation in human fatty acid amide hydrolase associated with problem drug use. Proc Natl Acad Sci USA 2002, 99:8394-8399.

29. Lasky-Su J, Lyon HN, Emilsson V, Heid IM, Molony C, Raby BA, Lazarus R, Klanderman B, Soto-Quiros ME, Avila L, Silverman EK, Thorleifsson G, Thorsteinsdottir U, Kronenberg F, Vollmert C, Illig T, Fox CS, Levy D, Laird N, Ding X, McQueen MB, Butler J, Ardlie K, Papoutsakis C, Dedoussis G, O'Donnell CJ, Wichmann HE, Celedón JC, Schadt E, Hirschhorn J, Weiss ST, Stefansson K, Lange C: On the replication of genetic associations: timing can be everything! Am J Hum Genet 2008, 82:849-858.

30. Heid IM, Huth C, Loos RJ, Kronenberg F, Adamkova V, Anand SS, Ardlie K, Biebermann H, Bjerregaard P, Boeing H, Bouchard C, Ciullo M, Cooper JA, Corella D, Dina C, Engert JC, Fisher E, Francès F, Froguel P, Hebebrand J, Hegele RA, Hinney A, Hoehe MR, Hu FB, Hubacek JA, Humphries SE, Hunt SC, Illig T, Järvelin MR, Kaakinen M, Kollerits B, Krude H, Kumar J, Lange LA, Langer B, Li S, Luchner A, Lyon HN, Meyre D, Mohlke KL, Mooser V, Nebel A, Nguyen TT, Paulweber B, Perusse L, Qi L, Rankinen T, Rosskopf D, Schreiber S, Sengupta S, Sorice R, Suk A, Thorleifsson G, Thorsteinsdottir U, Völzke H, Vimaleswaran KS, Wareham NJ, Waterworth D, Yusuf S, Lindgren C, McCarthy MI, Lange C, Hirschhorn JN, Laird N, Wichmann HE: Metaanalysis of the INSIG2 association with obesity including 74,345 individuals: does heterogeneity of estimates relate to study design? PLoS Genet 2009, 5:e1000694.

31. Walley AJ, Asher JE, Froguel P: The genetic contribution to nonsyndromic human obesity. Nat Rev Genet 2009, 10:431-442.

32. Hinney A, Hebebrand J: Three at One Swoop! Obes Facts 2009, 2:3-8.

33. Den Dunnen JT, Antonarakis SE: Nomenclature for the description of human sequence variations. Hum Genet 2001, 109:121-124. 
34. Knapp M, Becker T: Family-based association analysis with tightly linked markers. Hum Hered 2003, 56:2-9.

\section{Pre-publication history}

The pre-publication history for this paper can be accessed here: http://www.biomedcentral.com/1471-2350/11/2/prepub

doi: 10.1186/1471-2350-11-2

Cite this article as: Müller et al., Mutation screen and association studies for the fatty acid amide hydrolase (FAAH) gene and early onset and adult obesity BMC Medical Genetics 2010, 11:2 